\title{
ARTICLE
}

\section{Characterization of an acidophilic a-amylase from Aspergillus niger RBP7 and study of catalytic potential in response to nutritionally important heterogeneous compound}

\author{
Riddha Mukherjee1, Tanmay Paul ${ }^{1}$, Suman Kumar Halder ${ }^{1}$, Jyoti Prakash Soren ${ }^{1}$, \\ Amrita Banerjee ${ }^{1}$, Keshab Chandra Mondal ${ }^{1}$, Bikash Ranjan Pati ${ }^{1}$, Pradeep Kumar Das \\ Mohapatra ${ }^{2 *}$
}

${ }^{1}$ Department of Microbiology, Vidyasagar University, Midnapore - 721102, West Bengal, India

${ }^{2}$ Department of Microbiology, Raiganj University, Raiganj - 733134, Uttar Dinajpur, West Bengal, India

\begin{abstract}
An acidophilic a-amylase from Aspergillus niger RBP7 was purified after solid state fermentation on potato peel substrate. Molecular mass of the purified a-amylase was $37.5 \mathrm{kDa}$ and it exhibited $1.4 \mathrm{mg} / \mathrm{ml}$ and $0.992 \mu / \mathrm{mol} / \mathrm{min} \mathrm{K}_{\mathrm{m}}$ and $\mathrm{V}_{\max }$ values, respectively. The enzyme was stable in the $\mathrm{pH}$ range from 2.0 to 6.0 , at high $\mathrm{NaCl}$ concentration (3 M) and at temperatures between $40^{\circ} \mathrm{C}$ and $70{ }^{\circ} \mathrm{C}$. The enzyme showed an optimal activity at $\mathrm{pH} 3.0$ and at $45^{\circ} \mathrm{C}$. The enzyme was inhibited by $\mathrm{Hg}^{2+}$ and was stable in the presence of different surfactants (Tween 60, Tween 80, and SDS at $1 \%$ level) and different inhibitory reagents ( $\beta$-mercaptoethanol, phenylmethylsulfonyl fluoride, and sodium azide). This acidophilic amylase enzyme can digest heterogeneous food materials, i.e. the mixture of rice, fish, bread and curry with comparable activity to the commercial diastase enzymes available.

Acta Biol Szeged 62(1):75-82 (2018)
\end{abstract}

\section{KEY WORDS}

characterization

digestion of food material

molecular weight determination, purification

\author{
ARTICLE INFORMATION \\ Submitted \\ 7 December 2017 \\ Accepted \\ 21 May 2018. \\ *Corresponding author \\ E-mail: pkdmvu@gmail.com
}

\section{Introduction}

$\alpha$-Amylase is a starch hydrolyzing enzyme generating glucose and maltose as end products. It has high market value in different sectors and the market size of amylase in baking industry was 67476.6 tons in 2015. The use of $\alpha$-amylase in food and beverage industries is expected to be increased by 1.9\% from 2016 to 2024 in North America. Acidophilic amylases are applied in different industries like the glucose and fructose syrup production, bakery industry and fruit juice and digestive syrup producing industries (Souza and Magalhães 2010; Parker et al. 2010).

Various bacterial and fungal isolates can produce acidophilic amylases; most of them are belonging to the genus Bacillus and Aspergillus. In general, the acidophilic amylases can digest different raw starchy food ingredients (Maity et al. 2010; Mukherjee et al. 2017), therefore, they are frequently used to remove such food materials from various surfaces (e.g., textile). In the starch processing industries, acidophilic amylases are used to produce glucose in high amount from the starch polymer (Konsula and Liakopoulou-Kyriakides 2004; Haq et al. 2010; Khan and Priya 2011; Raghu and Rajeswara 2015). In bakery industry, acidophilic amylases are used to enhance the porosity, flavor and taste of the product (Gupta et al. 2003); amylases are also used for the clarification of beer and fruit juices (Gavrilescu and Chisti 2005; Ghorai et al. 2009).

In the present study, physicochemical characterization of an $\alpha$-amylase produced by the Aspergillus niger RBP7 isolate was evaluated. In addition, the digestion of starchy materials present in nutritionally important heterogeneous foods was also studied comparing the activity of the purified amylase with some commercially available diastases.

\section{Materials and Methods}

\section{Microorganism and culture condition}

Aspergillus niger RBP7 (GenBank KX100578.1) was isolated from municipal garbage area of Midnapore, West Bengal, India (Mukherjee et al. 2017). The fungal culture was maintained on Czapek Dox agar slants $(\mathrm{pH} 3)$ and stored at $4{ }^{\circ} \mathrm{C}$.

\section{Amylase production and enzyme extraction}

Enzyme production was carried out using potato peel 
as substrate following the method of Mukherjee and coworkers (2017). In the fermentation process, $1.2 \mathrm{~g}$ of potato peel was moistened with $1 \mathrm{ml}$ liquid medium $\left(\mathrm{NaNO}_{3} 0.3\right.$ $\mathrm{g}, \mathrm{MgSO}_{4} 0.05 \mathrm{~g}, \mathrm{KCl} 0.05 \mathrm{~g}, \mathrm{FeSO}_{4} 0.002 \mathrm{~g}$, and $\mathrm{K}_{2} \mathrm{HPO}_{4}$ $0.1 \mathrm{~g}) ; \mathrm{pH}$ and temperature were adjusted to 2.7 and 44 ${ }^{\circ} \mathrm{C}$, respectively (Mukherjee et al. 2017). The flasks were autoclaved at $121{ }^{\circ} \mathrm{C}$ for $20 \mathrm{~min}$ at 15 psi pressure. The flasks were cooled, inoculated with $1 \mathrm{ml}\left(2 \times 10^{2}\right.$ spores $)$ of $A$. niger RBP7, and incubated at $27^{\circ} \mathrm{C}$ for $96 \mathrm{~h}$. After fermentation, $5 \mathrm{ml}$ of sterile distilled water was added to each flask and vigorously agitated in rotary shaker at $100 \mathrm{rpm}$ for $30 \mathrm{~min}$. The mixture was filtered through cheese cloth and centrifuged at $8000 \mathrm{rpm}$ for $10 \mathrm{~min}$. The supernatant was taken as crude enzyme preparation and used for subsequent experiments.

\section{Assay of amylase activity and protein content}

$\alpha$-Amylase activity was determined by incubating $1 \mathrm{ml}$ reaction mixture containing $0.5 \mathrm{ml}$ of enzyme source and $1 \%$ soluble starch dissolved in $0.2 \mathrm{M}$ acetate buffer $(\mathrm{pH} 3.0)$ at $37^{\circ} \mathrm{C}$ for $1 \mathrm{~h}$. The reaction was stopped by $1 \mathrm{ml}$ of 3.5-dinitrosalicylic acid (Merck, India) mixed with the above mixture. Then the mixture was boiled in water bath for $10 \mathrm{~min}$. The produced reducing sugar was measured at $540 \mathrm{~nm}$. One unit (U) of $\alpha$-amylase activity was determined as the amount of enzyme that releases $1 \mu \mathrm{mol}$ of reducing sugar as glucose equivalent. The protein content of enzyme solution was estimated according to Lowry et al. (1951) using bovine serum albumin as standard.

\section{Enzyme purification}

All purification steps were carried out at $4{ }^{\circ} \mathrm{C}$. After the 96-h fermentation, the crude enzyme was salted out with $80 \%$ ammonium sulfate and kept overnight at $4{ }^{\circ} \mathrm{C}$. Then, the solution was centrifuged at $10000 \mathrm{rpm}$ for $10 \mathrm{~min}$ and the precipitate was dissolved in $5 \mathrm{ml}$ acetate buffer (0.2 M, pH 3.0). After dialysis against distilled water (24 h), the dialysate was loaded onto $2.5 \mathrm{~cm} \times 70 \mathrm{~cm}$ Sephadex G-100 column (Sigma Aldrich, USA), equilibrated with acetate buffer $(0.2 \mathrm{M}, \mathrm{pH} 3.0)$ and eluted with the same buffer at a flow rate of $1 \mathrm{ml} / \mathrm{min}$. A volume of $2 \mathrm{ml}$ fractions was collected and the amylase activity and the protein content in each fraction were determined.

\section{Molecular weight determination and zymogram analysis}

Sodium dodecyl sulfate-polyacrylamide gel electrophoresis (SDS-PAGE) was carried out by using a 10\% (w/v) polyacrylamide gel. Protein bands were detected by staining the gel with Coomassie Brilliant Blue R250 (Laemmli 1970). For zymography, non-denaturing PAGE $(10 \%, w / v)$ was performed (Halder et al. 2016) at $4{ }^{\circ} \mathrm{C}$ and the gel was subsequently washed with deionized water and $0.2 \mathrm{M}$ acetate buffer ( $\mathrm{pH} 3.0$ ) at $40{ }^{\circ} \mathrm{C}$. Then, the gel was incubated in fresh acetate buffer containing $1 \%(\mathrm{w} / \mathrm{v})$ soluble starch at $40{ }^{\circ} \mathrm{C}$ for $30 \mathrm{~min}$. After washing with distilled water, the gel was stained with iodine solution until the clear zone of starch hydrolysis was appeared against the dark blue background.

\section{Determination of the $\mathrm{pH}$ and temperature optimum and stability}

The effect of $\mathrm{pH}$ on the activity was estimated in hydrochloric acid and sodium acetate buffer for $\mathrm{pH} 2.0$ (Uchino 1982) and acetate buffer for $\mathrm{pH}$ range of 3.0 - 6.0 using $1 \%$ starch as substrate. The $\mathrm{pH}$ stability was determined by pre-incubating the enzyme under conditions between $\mathrm{pH} 2.0-6.0$ for 1 to 6 hours. The residual activity was measured according to the standard protocol as described above. For determination of optimum temperature, the assay was performed at the temperature range of $20{ }^{\circ} \mathrm{C}$ - $60{ }^{\circ} \mathrm{C}$. Temperature stability of the purified $\alpha$-amylase was measured by incubating the enzyme at different temperatures between $40^{\circ} \mathrm{C}$ and $70^{\circ} \mathrm{C}$ for different time intervals (20 to $120 \mathrm{~min}$ ). The residual amylase activity was measured under standard assay conditions described above.

\section{Detection of temperature quotient $\left(Q_{10}\right)$}

Temperature quotient $\left(\mathrm{Q}_{10}\right)$ denoted the changes in the rate of the enzymatic catalytic reaction at every $10{ }^{\circ} \mathrm{C}$ rise in temperature: $\mathrm{Q}_{10}=\left(\mathrm{R}_{2} / \mathrm{R}_{1}\right)^{10 /\left(\mathrm{T}_{2}-\mathrm{T}_{1}\right)}$

Where $T_{1}$ and $T_{2}$ are the initial and final temperatures at which experiment was conducted. $\mathrm{R}_{1}$ and $\mathrm{R}_{2}$ are the amylase activity at $T_{1}$ and $T_{2}$, respectively.

\section{Effects of additives on enzyme activity}

To study the effects of various additives on purified enzyme activity, the enzyme was pre-incubated for $1 \mathrm{~h}$ at optimum assay conditions with solutions of the followings additives.

Metal ions: $\mathrm{Ca}^{2+}\left(\mathrm{CaCl}_{2}\right), \mathrm{Mg}^{2+}\left(\mathrm{MgSO}_{4}\right), \mathrm{Zn}^{2+}\left(\mathrm{ZnSO}_{4}\right)$, $\mathrm{Mn}^{2+}\left(\mathrm{MnSO}_{4}\right), \mathrm{Cu}^{2+}\left(\mathrm{CuSO}_{4}\right), \mathrm{K}^{+}\left(\mathrm{K}_{2} \mathrm{SO}_{4}\right), \mathrm{Ag}^{+}\left(\mathrm{AgSO}_{4}\right)$, $\mathrm{Fe}^{3+}\left(\mathrm{Fe}_{3} \mathrm{SO}_{4}\right)$, and $\mathrm{Co}^{2+}\left(\mathrm{CoCl}_{2}\right)$ at final concentration of $1 \mathrm{mM}$ and $5 \mathrm{mM}$. After $1 \mathrm{~h}$, we added substrate in each reaction mixture containing additives and incubated the reaction under standard assay condition to get the enzyme activity.

For determining the stability with surfactants, SDS, Tween 60, Tween 80 and Triton X-100 with different concentrations ( $1 \%, 2 \%$ and $3 \% \mathrm{w} / \mathrm{v}$ ) were used. Chelating agents like ethylenediaminetetraacetic acid (EDTA) with the concentration of 1,2 and $3(\%, w / v)$ were used. Phenylmethylsulfonyl fluoride (PMSF), $\beta$-mercaptoethanol, and sodium azide $(1 \%, 2 \%$ and $3 \% \mathrm{w} / \mathrm{v})$ were used as inhibitor for testing the enzyme stability. 
Table 1. Purification profile of amylases

\begin{tabular}{llllll}
\hline Steps for purification & $\begin{array}{l}\text { Total activity } \\
(\mathrm{U})\end{array}$ & $\begin{array}{l}\text { Total protein } \\
(\mathrm{mg})\end{array}$ & $\begin{array}{l}\text { Specific activity } \\
(\mathrm{U} / \mathrm{mg})\end{array}$ & Fold purification & $\begin{array}{l}\text { Recovery } \\
(\%)\end{array}$ \\
\hline Crude enzyme & 292500 & 8117.5 & 36.03 & 1 & 100 \\
Ammonium sulfate precipitation & 122465 & 846.9 & 144.6 & 4.01 & 41.86 \\
Sephadex G-100 & 8812.7 & 14.34 & 335.61 & 9.31 & 7.19 \\
\hline
\end{tabular}

Solvents (1\%, v/v) like acetone, methanol, butanol, propanol, toluene, hexane, ethanol, xylene, acetonitrile were used to estimate their effect on enzyme activity. In all cases, the residual activity was measured.

\section{Halo-stability of purified acidophilic a-amylase}

The purified enzyme was incubated with various concentrations of $\mathrm{NaCl}(0-5.0 \mathrm{M})$ for $1 \mathrm{~h}$ at room temperature, and the residual $\alpha$-amylase activity was measured following the standard protocol.

\section{Storage stability and light sensitivity}

For determining the storage stability, the two sets of enzymes were incubated (in acetate buffer, $\mathrm{pH} 3.0$ ) for 14 days at $4{ }^{\circ} \mathrm{C}$ and in room temperature $\left(37^{\circ} \mathrm{C}\right)$ as control. The light sensitivity test was investigated by incubating the enzyme in sun light $\left(40{ }^{\circ} \mathrm{C}\right)$ for 14 days. The enzyme activity was checked following the standard assay protocol after sampling at the $7^{\text {th }}$ and $14^{\text {th }}$ days.

\section{Substrate specificity and enzyme kinetics}

Different polysaccharides were used for determination of the spectrum of substrate specificity of the enzyme. The tested substrates were soluble starch (Merck, India), amylose (Merck, India), amylopectin (Merck, India), dextran (HiMedia, India) and pullulan (HiMedia, India) at a concentration of $1.0 \%(\mathrm{w} / \mathrm{v})$ in $0.2 \mathrm{M}$ acetate buffer $(\mathrm{pH}$ 3.0). All assays were performed following the standard protocol for enzyme activity determination.

The kinetic constants $\left(\mathrm{K}_{\mathrm{m}}\right.$ and $\left.\mathrm{V}_{\max }\right)$ were estimated by double reciprocal plots of the data according to standard method of Lineweaver and Burk (1934) with Sigma Plot Enzyme kinetics software module 1.3 (Systat Software, USA). Michaelis-Menten plot was also drawn using the same software. Equation of Lineweaver Burk plot: 1/ $\mathrm{V}_{\max }=\mathrm{K}_{\mathrm{m}} / \mathrm{V}_{\max } \times 1 /[\mathrm{s}]+1 / \mathrm{V}_{\max }$ The turnover number and catalytic efficiency were estimated from the following formula: Turnover number $\left(\mathrm{K}_{\mathrm{cat}}\right)=\mathrm{V}_{\max } / \mathrm{E}_{\mathrm{t}}$ (total enzyme), Catalytic efficiency $=\mathrm{K}_{\mathrm{cat}} / \mathrm{K}_{\mathrm{m}}$

\section{Study of enzymatic efficiency}

Here we used the mixed food materials as substrate to know the activity of purified acidophilic $\alpha$-amylase and different commercial amylase in heterogeneous condition of food. In this study different commercial alpha amylases were used, e.g., Carmozyme ${ }^{\mathrm{TM}}$ (Mendine Pharmaceuticals, India), Unienzyme ${ }^{\mathrm{TM}}$ (Unichem Laboratories), Aristozyme $^{\mathrm{TM}}$ (Aristo Pharmaceuticals), Vitazyme ${ }^{\mathrm{TM}}$ (East India Pharmaceutical). Briefly, a mixed preparation of food materials, i.e. rice, fish, bread and vegetable curry, was crushed into small pieces. Then the raw material was smashed with a homogenizer with the addition of acetate buffer ( $\mathrm{pH}$ 3.0). The whole matter was considered as substrate $(1 \mathrm{ml})$ and was incubated with $1 \mathrm{ml}(150 \mathrm{U})$ of purified enzyme and different commercial enzyme preparations $(150 \mathrm{U} / \mathrm{ml})$. After incubation the reducing sugars of each experimental set were determined according to dinitrosalicylic acid method.

\section{Results and Discussion}

\section{Enzyme production}

The A. niger RBP7 produced $1112.25 \mathrm{U} / \mathrm{gds}$ of $\alpha$-amylase in $72 \mathrm{~h}$ fermentation period at $40^{\circ} \mathrm{C}$ and $\mathrm{pH} 3.0$ (Mukherjee et al. 2017). This crude amylolytic solution was used for the enzyme purification.

\section{Purification of the a-amylase}

The $\alpha$-amylase from A. niger RBP7 was purified by ammonium sulfate precipitation followed by a size exclusion chromatography step using Sephadex G100 resin. The purified enzyme had a specific activity of $335.61 \mathrm{U} / \mathrm{mg}$ of protein. The molecular weight of enzyme was found to be approximately $37.5 \mathrm{kDa}$ (Fig. 1). The purification procedures are summarized in the Table 1 . The isolated enzyme was homogeneous, as seen by a single protein both in native and with reduced and denaturing condition. The protein band of purified $\alpha$-amylase was confirmed by the zymogram. The purified enzyme (single band) showed clear zone around the single band on starch containing zymogram when the zymogram was flooded with iodine solution (Fig. 1). The microbial $\alpha$-amylases generally have their molecular weight between 23 and $150 \mathrm{kDa}$ (Krishnan and Chandra 1983; Pandey et al. 2000). Fungal amylases from the A. niger JGI 24 and Monascus sanguineus have molecular weight of $43 \mathrm{kDa}$ and $56 \mathrm{kDa}$, respectively (Varalakshmi et al. 2009; Tallapragada et al. 2017). 


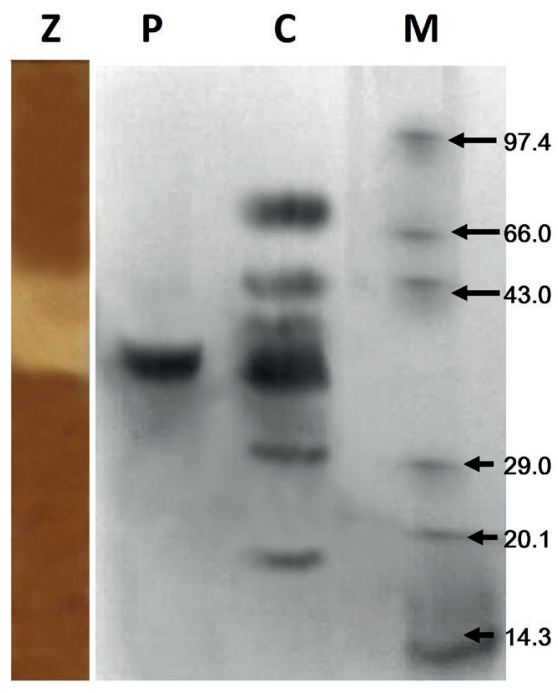

Figure 1. PAGE analysis of each fraction during purification. Z: zymogram; P: purified enzyme; C: crude enzyme; M: molecular weight marker $(k D)$ after column chromatography.

\section{Effect of the $\mathrm{pH}$ and temperature on the activity and stability of the enzyme}

The purified $\alpha$-amylase exhibited the maximal starch hydrolysis at $\mathrm{pH} 3.0$ (Fig. 2). The enzyme was stable in pHs between 2.0 and 6.0 for 60 to 300 min incubation period (Fig. 3). The purified $\alpha$-amylase showed maximum amylolytic activity at $45^{\circ} \mathrm{C}$ (Fig. 4) and it was stable during incubation at $40-70{ }^{\circ} \mathrm{C}$ for 20 to $120 \mathrm{~min}$ (Fig. 5). Yandri et al. (2012) reported that $\alpha$-amylase from Bacillus subtilis ITBCCB 148 can work between $\mathrm{pH} 5.0$ and 9.0 and maximum activity showed at $\mathrm{pH}$ 6.0. The Streptomyces sp. MSC702 $\alpha$-amylase have optimum activity at $60^{\circ} \mathrm{C}$ and the enzyme was stable between 20 and $80^{\circ} \mathrm{C}$ (Singh et al. 2014). Aygan et al. (2008) reported that the $\alpha$-amylase obtained from Bacillus sp. AB 68 was active in a broad range of temperature $\left(20\right.$ to $\left.90^{\circ} \mathrm{C}\right)$, with an optimum of $50{ }^{\circ} \mathrm{C}$. The Aspergillus terreus amylase have its optimum activity at $\mathrm{pH} 5.0$, but it is stable at different $\mathrm{pHs}(\mathrm{pH} 3.0$ - 10.0) (Sethi et al. 2016).

\section{Temperature quotient $\left(Q_{10}\right)$}

Temperature quotient $\left(\mathrm{Q}_{10}\right)$ is mainly used to study the dependence of enzyme catalytic reaction rate on temperature. Results showed that temperature quotient $\left(\mathrm{Q}_{10}\right)$ of the acidophilic amylase is 1.065 at $45{ }^{\circ} \mathrm{C}$. The temperature coefficient value $\left(\mathrm{Q}_{10}\right)$ for Bacillus licheniformis SKB4 $\alpha$-amylase was found to be 1.0 (Samanta et al. 2014). This $\mathrm{Q}_{10}$ value is calculated in order to know whether temperature is crucial factor for enzymatic reaction or not. For enzymatic catalysis range of $\mathrm{Q}_{10}$ value is generally 1-2, and any deviation from that there are other influencing factors which controlling the enzyme activity. In our case

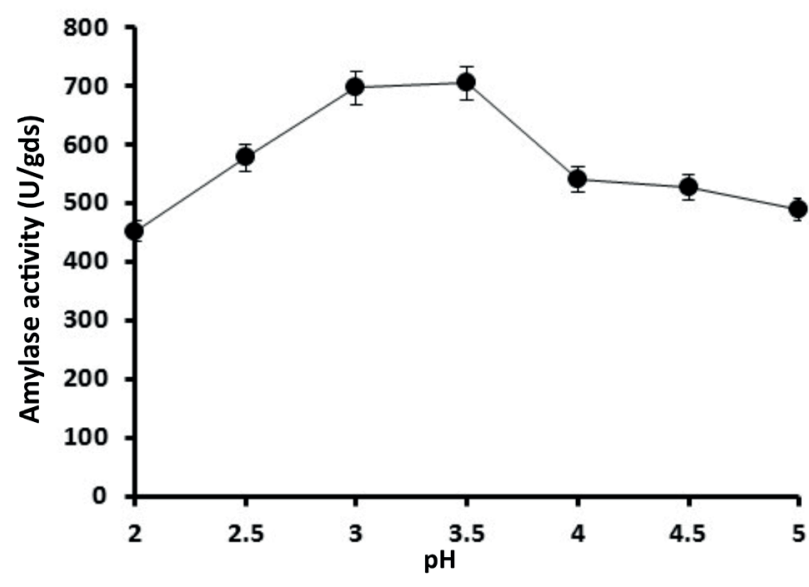

Figure 2. Activity of a-amylase at different $\mathrm{pH}$

the $\mathrm{Q}_{10}$ value is 1.065, which indicates that temperature is crucial factor for enzymatic action.

\section{Effect of additives on a-amylase}

Metal salts have both enhancing and inhibitory effects on the enzyme activity and stability. Therefore, metal compatibility profiling of an enzyme is very important to find out its optimum catalytic conditions. In this study, it was observed that each metal had inhibitory effect on enzyme activity (Table 2). More than $40 \%$ of the activity was lost in presence of all the salt tested in $5 \mathrm{mM}$ concentration. In the presence of $3 \%$ EDTA and $\beta$-mercaptoethanol, the relative activity of the enzyme decreased by $72 \%$ and $82 \%$, respectively. The enzyme activity decreased drastically to about $75 \%$ in presence of the solvents tested. This may be due to the amino acid composition as well as three dimensional structures, which endorsed relative resistance of the enzyme against hydrophobic/non-polar micro environment (Halder et al. 2016).

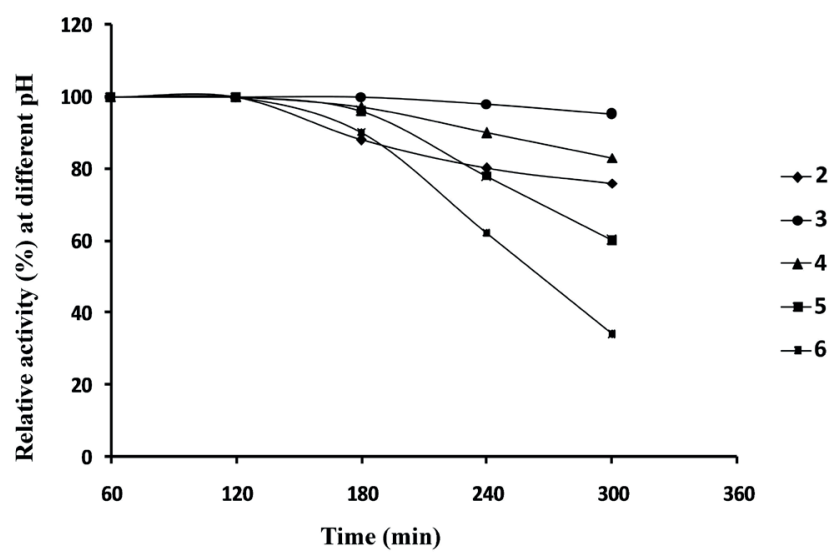

Figure 3. Effect of $\mathrm{pH}$ on the stability of purified a-amylase of A. niger RBP7 
Table 2. Effect of additives on purified a-amylase of A. niger RBP7

\begin{tabular}{|c|c|c|}
\hline Metal ion & Concentration & Relative activity (\%) \\
\hline \multirow[t]{2}{*}{$\mathrm{K}^{+}$} & $1 \mathrm{mM}$ & 53.53 \\
\hline & $5 \mathrm{mM}$ & 53.12 \\
\hline \multirow[t]{2}{*}{$\mathrm{Cu}^{2+}$} & $1 \mathrm{mM}$ & 60.2 \\
\hline & $5 \mathrm{mM}$ & 58.1 \\
\hline \multirow[t]{2}{*}{$\mathrm{Fe}^{3+}$} & $1 \mathrm{mM}$ & 56.86 \\
\hline & $5 \mathrm{mM}$ & 55.61 \\
\hline \multirow[t]{2}{*}{$\mathrm{Mg}^{2+}$} & $1 \mathrm{mM}$ & 59.35 \\
\hline & $5 \mathrm{mM}$ & 58.9 \\
\hline \multirow[t]{2}{*}{$\mathrm{Zn}^{2+}$} & $1 \mathrm{mM}$ & 61.01 \\
\hline & $5 \mathrm{mM}$ & 59.34 \\
\hline \multirow[t]{2}{*}{$\mathrm{CO}^{2+}$} & $1 \mathrm{mM}$ & 60.6 \\
\hline & $5 \mathrm{mM}$ & 53.54 \\
\hline \multirow[t]{2}{*}{$\mathrm{Ca}^{2+}$} & $1 \mathrm{mM}$ & 60.6 \\
\hline & $5 \mathrm{mM}$ & 57.6 \\
\hline \multirow[t]{2}{*}{$\mathrm{Ag}^{+}$} & $1 \mathrm{mM}$ & 61.8 \\
\hline & $5 \mathrm{mM}$ & 57.6 \\
\hline \multirow[t]{2}{*}{$\mathrm{Mn}^{2+}$} & $1 \mathrm{mM}$ & 60.17 \\
\hline & $5 \mathrm{mM}$ & 58.5 \\
\hline \multicolumn{3}{|l|}{ Surfactant } \\
\hline \multirow[t]{3}{*}{ SDS } & $1 \%$ & 34.03 \\
\hline & $2 \%$ & 32.8 \\
\hline & $3 \%$ & 23.24 \\
\hline \multirow[t]{3}{*}{ Tween 60} & $1 \%$ & 43.6 \\
\hline & $2 \%$ & 37 \\
\hline & $3 \%$ & 35.7 \\
\hline \multirow[t]{3}{*}{ Tween 80} & $1 \%$ & 51.05 \\
\hline & $2 \%$ & 40.7 \\
\hline & $3 \%$ & 40.26 \\
\hline \multirow[t]{3}{*}{ Triton $\mathrm{X}$} & $1 \%$ & 40.26 \\
\hline & $2 \%$ & 33.6 \\
\hline & $3 \%$ & 30.7 \\
\hline \multicolumn{3}{|l|}{ Solvent } \\
\hline Acetone & $1 \%$ & 22.8 \\
\hline Methanol & $1 \%$ & 25.31 \\
\hline Butanol & $1 \%$ & 22 \\
\hline Propanol & $1 \%$ & 22.83 \\
\hline Toluene & $1 \%$ & 22 \\
\hline Hexane & $1 \%$ & 23.5 \\
\hline Ethanol & $1 \%$ & 23.65 \\
\hline Xylene & $1 \%$ & 22.4 \\
\hline Acetonitrile & $1 \%$ & 22.83 \\
\hline \multicolumn{3}{|l|}{ Chelating agent } \\
\hline \multirow[t]{3}{*}{ EDTA } & $1 \%$ & 32.8 \\
\hline & $2 \%$ & 31.12 \\
\hline & $3 \%$ & 28.21 \\
\hline \multicolumn{3}{|l|}{ Inhibitory agent } \\
\hline \multirow[t]{3}{*}{ PMSF } & $1 \%$ & 46.48 \\
\hline & $2 \%$ & 46.48 \\
\hline & $3 \%$ & 44.82 \\
\hline \multirow[t]{3}{*}{$\beta$-mercaptoethanol } & $1 \%$ & 20.75 \\
\hline & $2 \%$ & 20.33 \\
\hline & $3 \%$ & 17.84 \\
\hline Sodium azide & $1 \%$ & 45.7 \\
\hline & $2 \%$ & 45.23 \\
\hline & $3 \%$ & 37.8 \\
\hline
\end{tabular}

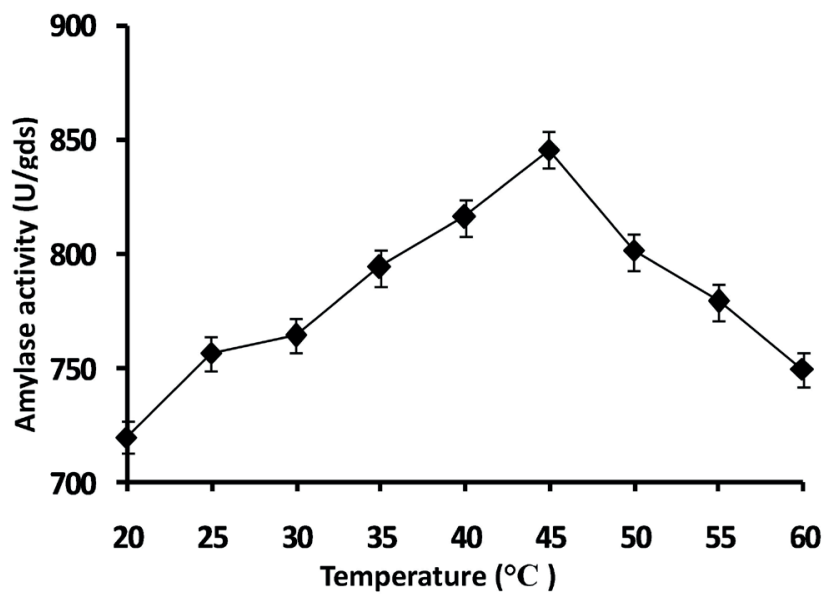

Figure 4. Activity of a-amylase at different temperature

\section{Effect of $\mathrm{NaCl}$ on the purified a-amylase}

The high salt tolerance capability of enzyme is very important for its commercialization in bioprocess industry. Enzymatic activity of $\alpha$-amylase was tested in presence of $\mathrm{NaCl}(0-5.0 \mathrm{M})$. Salt tolerant capacity of acidophilic amylase from $A$. niger $\mathrm{RBP7}$ at various $\mathrm{NaCl}$ concentrations shown in Fig. 6. It was found that $\mathrm{NaCl}$ was not required for activity; however, maximum starch hydrolyzing activity (808 U/gds) was observed in the presence of $3 \mathrm{M}$ of $\mathrm{NaCl}$. The enzyme was found to be salt-tolerant since the hydrolysis also proceeded well in the presence of $5 \mathrm{M}$ $\mathrm{NaCl}$. Previous study showed that $\alpha$-amylases produced by Bacillus sp MD124 was stable in $1 \mathrm{M} \mathrm{NaCl}$ concentration (Jana and Pati 1997). Amylase activity was $0.105 \mathrm{U} /$ $\mathrm{ml}$ and inhibited by $44.7 \% \mathrm{NaCl}$ produced by Monascus sanguineus reported by Tallapragada et al. (2017). There was a salt tolerant amylase produced by Bacillus $\mathrm{sp}$. MD124 which was found to be retained $75 \%$ of its activity in 5.0

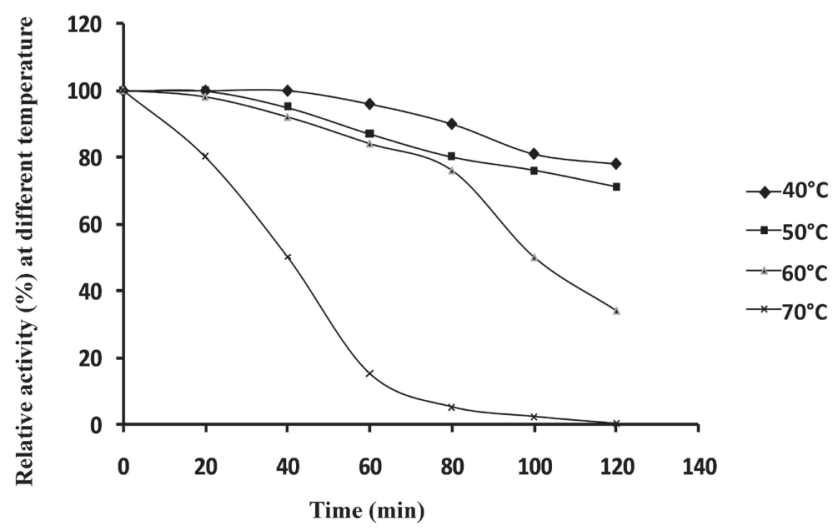

Figure 5. Effect of temperature on the stability of purified a-amylase of A. niger RBP7 


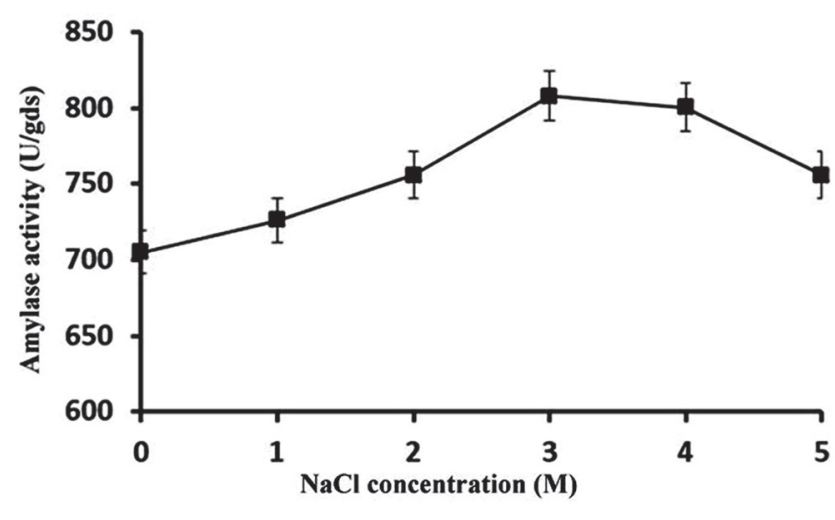

Figure 6. Activity of a-amylase at different concentration of $\mathrm{NaCl}$

$\mathrm{M}$ of $\mathrm{NaCl}$ concentration (Jana et al. 1997).

\section{Storage stability and light sensitivity}

The purified amylase retained about $90 \%$ of its activity after 14 days incubation at room temperature (Fig. 7) and retain $97 \%$ activity in freezing condition. Enzyme retains its $95.4 \%$ activity after 14 days of incubation.

\section{Substrate specificity and enzyme kinetics}

The enzyme was active on soluble starch, amylose, amylopectin. It was found that the hydrolytic efficiency was different from substrate to substrate and the descending order of efficiency as follows: soluble starch $>$ amylose $>$ amylopectin. Pullulan was not cleaved by the enzyme. The enzyme showed Michaelis-Menten kinetic on soluble starch applied in various concentrations (Fig. 8). Kinetic parameter $\left(\mathrm{V}_{\max }, \mathrm{K}_{\mathrm{m}}, \mathrm{K}_{\mathrm{cat}}\right.$ and catalytic efficiency) values for the hydrolysis of soluble starch by $\alpha$-amylase were $\mathrm{K}_{\mathrm{m}}(1.4 \mathrm{mg} / \mathrm{ml}), \mathrm{V}_{\max }(0.992 \mu \mathrm{mol} / \mathrm{min}), \mathrm{K}_{\mathrm{cat}} 2.9796 \mathrm{~min}^{-}$ ${ }^{1}$ and catalytic efficiency $5.0693 \mathrm{mg} / \mathrm{ml} / \mathrm{min}$ (Fig. 8a, b; $\mathrm{V}_{0}=\mathrm{V}_{\max }[\mathrm{S}] / \mathrm{K}_{\mathrm{m}}+[\mathrm{S}]$ ). The result of the relationship between substrate concentration and enzyme activity of substrates reveal that the activity of the enzyme increased concomitantly with an increase in substrate concentration. But the enzyme activity stopped to increase when the concentration exceeded $4 \mathrm{mg} / \mathrm{ml}$ indicating that substrate saturation was taking place. Haq et al. (2010) reported that $\alpha$-amylase with $\mathrm{K}_{\mathrm{m}}$ value of $4.11 \mathrm{mg} / \mathrm{ml}$ and

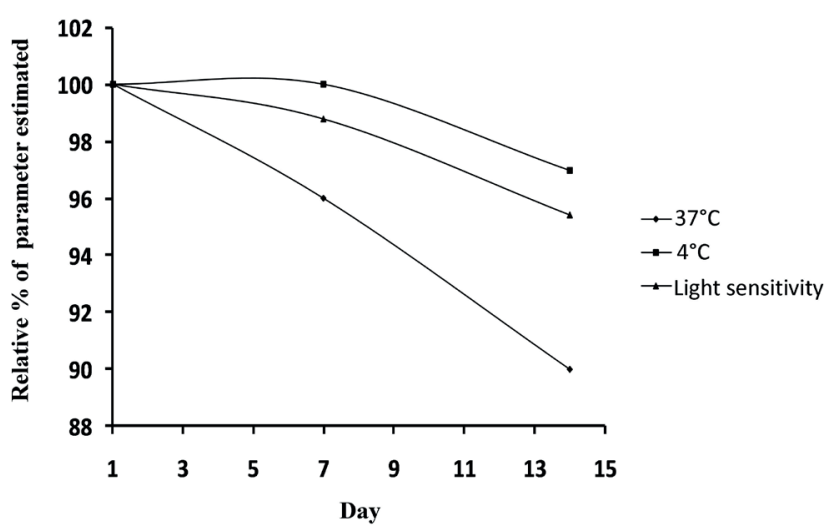

Figure 7. Effect of storage time and light sensitivity on stability of a-amylase of A. niger RBP7

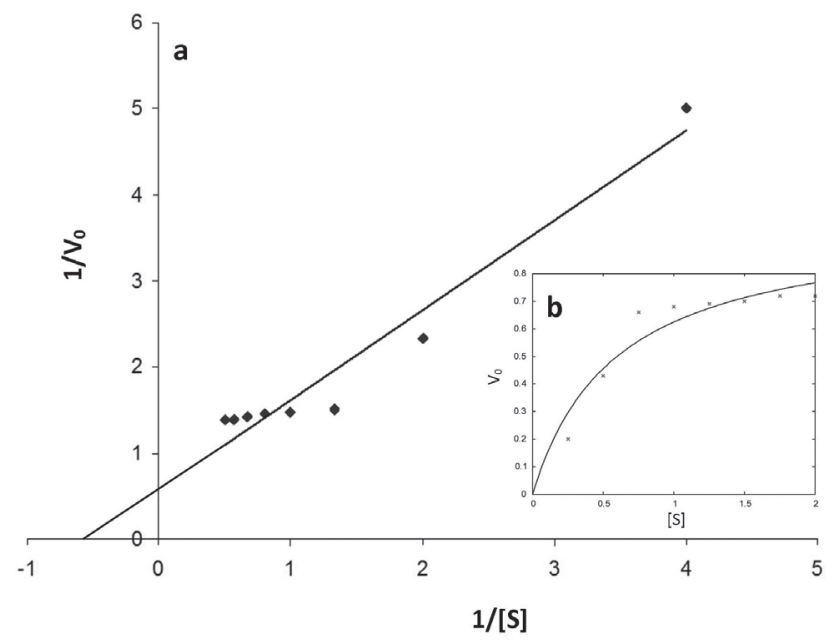

Figure 8. Lineweaver-Burk (a) and Michaelis-Menten (b) plots of enzyme kinetics of purified a-amylase at optimum $\mathrm{pH}$ and temperature

$\mathrm{V}_{\max }$ value $0.45 \mathrm{mg}$ with soluble starch as substrate from B. licheniformis EMS-6.

\section{Enzymatic efficiency and bioconversion of heteroge- neous nutritionally important compound}

In these studies, mixture of food ingredients, i.e. rice, bread, fish and vegetable curry were digested with the

Table 3. Comparison of a-amylase from RBP7 with the commercially available Diastase

\begin{tabular}{llll}
\hline Enzyme & Enzyme activity $(\mathrm{U} / \mathrm{ml})$ & Specific activity $(\mathrm{U} / \mathrm{mg})$ & Reducing sugar $(\mu \mathrm{g} / \mathrm{ml})$ \\
\hline Carmozyme $^{\mathrm{TM}}$ & 157.36 & 15.73 & 78.65 \\
Vitazyme $^{\mathrm{TM}}$ & 118.3 & 29.57 & 29 \\
Aristrozyme $^{\mathrm{TM}}$ & 121.73 & 12.17 & 60.84 \\
Unienzyme $^{\mathrm{TM}}$ & 115.79 & 17.39 & 57.88 \\
a-Amylase from A. niger RBP7 & 155.9 & 5.5 & 77.91 \\
\hline
\end{tabular}


purified amylase of $A$. niger RBP7 and the performance was compared with some commercially available amylolytic cocktails. Results showed that the reducing sugar concentration after treatment with A. niger RBP7 $\alpha$-amylase was higher than those detected for most of the commercial enzymes tested. Only the Carmozyme cocktail resulted similar digestive capacity (Table 3 ). Anyway, the $\alpha$-amylase from $A$. niger RBP7 have the potential to degrade starchy materials present in the mixture of different food ingredients.

\section{Conclusion}

Acidophilic $\alpha$-amylase produced in SSF from A. niger RBP7 was purified by ammonium sulfate precipitation followed by gel filtration chromatography. The purified enzyme had molecular weight of $37.5 \mathrm{kDa}$ detected on SDS-PAGE and exhibited active band after zymography. It can hydrolyze starchy materials present in the mixture of rice, bread, fish and vegetable curry food products. The broad $\mathrm{pH}$ and temperature stability and the activity remained after long-time storage are also validate the possible application of the $A$. niger RBP7 $\alpha$-amylase as additive for digestive syrup cocktails.

\section{References}

Aygan A, Arikan B, Korkmaz H, Dinçer S, Colak O (2008) Highly thermostable and alkaline $\alpha$-amylase from a halotolerant-alkaliphilic Bacillus sp. AB68. Braz J Microbiol 39(3):547-553.

Gavrilescu M, Chisti Y (2005) Biotechnology - a sustainable alternative for chemical industry. Biotechnol Adv 23(7-8):471-499.

Ghorai, S, Banik SP, Verma D, Chowdhury S, Mukherjee S, Khowala $S$ (2009) Fungal biotechnology in food and feed processing. Food Res Int 42(5):577-587.

Gupta R, Gigras P, Mohapatra H, Goswami VK, Chauhan B (2003) Microbial $\alpha$-amylases: a biotechnological prospective. Process Biochem 38:1599-1616.

Halder SK, Jana A, Paul T, Das AP, Ghosh K, Pati BR, Mondal KC (2016) Purification and biochemical characterization of chitinase of Aeromonas hydrophila SBK1 biosynthesized using crustacean shell. Biocat Agri Biotechnol 5:211-218.

Haq I, Ali S, Javed MM, Hameed U, Saleem A, Adnan F, Qadeer MA (2010) Production of alpha amylase from a randomly induced mutant strain of Bacillus amyloliquefaciens and its application as a desizer in textile industry. Pak J Bot 42(1):473-484.

Haq IU, Javed MM, Hameed U, Adnan F (2010) Kinetic and thermodynamic studies of alpha amylase from Bacillus licheniformis mutant. Pak J Bot 42(5):3507-3516.

Jana M, Pati B (1997) Thermostable, salt-tolerant $\alpha$-amylase from Bacillus sp. MD 124.J Basic Microbiol 37(5):323-326.

Khan JA, Priya R (2011) A study on partial purification and characterization of extracellular amylases from Bacillus subtilis. Adv Appl Sci Res 2(3):509-519.

Konsula Z, Liakopoulou-Kyriakides M (2004) Hydrolysis of starches by the action of an $\alpha$-amylase from Bacillus subtilis. Process Biochem 39:1745-1749.

Krishnan T, Chandra AK (1983) Purification and characterization of $\alpha$-amylase from Bacillus licheniformis CUMC 305. Appl Environ Microbiol 46:430-437.

Laemmli UK (1970) Cleavage of structural proteins during the assembly of the head of bacteriophage T4. Nature 227:680-685.

Lineweaver H, Burk D (1934) The determination of enzyme dissociation constants. Acc Chem Res 56(3):658-666.

Lowry OH, Rosebrough NJ, Farr AL, Randall RJ (1951) Protein measurement with Folin phenol reagent. J Biol Chem 193:265-275.

Maity C, Samanta S, Halder SK, Das Mohapatra PK, Pati BR, Jana M, Mondal KC (2010) Isozymes of $\alpha$-amylases from newly isolated Bacillus thuringiensis CKB 19: production from immobilized cells. Biotechnol Bioprocess Eng 16(2):312-319.

Miller GL (1959) Use of dinitrosalicylic acid reagent for determination of reducing sugar. Anal Chem 31(3):426-428.

Mukherjee R, Paul T, Soren JP, Halder SK, Mondal KC, Pati BR, Das Mohapatra PK (2017) Acidophilic $\alpha$-amylase production from Aspergillus niger RBP7 using potato peel as substrate: a waste to value added. Waste Biomass Valor, https://doi.org/10.1007/s12649-017-0114-8.

Pandey A, Nigam P, Soccol CR, Soccol VT, Singh D, Mohan R (2000) Advances in microbial amylases. Biotechnol Appl Biochem 31(2):135-152.

Parker K, Salas M, Nwosu VC (2010) High fructose corn syrup: production, uses and public health concerns. Biotechnol Mol Biol Rev 5(5):71-78.

Raghu HS, Rajeshwara NA (2015) Immobilization of $\alpha$-amylase $(1,4-\alpha$-D-glucanglucanohydralase) by calcium alginate encapsulation. Int Food Res J 22(2):869-871.

Samanta S, Das A, Halder SK, Jana A, Kar S, Das Mohapatra PK, Pati BR, Mondal KC (2014) Thermodynamic and kinetic characteristics of an $\alpha$-amylase from Bacillus licheniformis SKB4. Acta Biol Szeged 58(2):147-156.

Sethi BK, Nanda PK, Sahoo S, Sena S (2016) Characterization of purified $\alpha$-amylase produced by Aspergillus terreus NCFT 4269.10 using pearl millet as substrate. Cogent Food Agric 2(1).

Singh R, Kumar V, Kapoor V (2014) Partial purification and characterization of heat stable $\alpha$-amylase from a thermophilic actinobacteria, Streptomyces sp. MSC 702. Enzyme Res 2014:8, ID 106363. 
Souza PMD, Magalhães PDOE (2010) Application of microbial $\alpha$-amylase in industry - a review. Braz J Microbiol 41:850-861.

Tallapragada P, Dikshit R, Jadhav A, Sarah U (2017) Partial purification and characterization of amylase enzyme under solid state fermentation from Monascus sanguineus. Genet Eng Biotechnol J 15(1):95-101.

Uchino F (1982) A thermophilic unusually acidophilic amylase produced by a thermophilic acidophilic Bacillus sp. Agric Biol Chem 46(1):7-13.
Varalakshmi KN, Kumudini BS, Nandini BN, Solomon J, Suhas R, Mahash B, Kavitha AP (2009) Production and characterization of $\alpha$-amylase from Aspergillus niger JGI 24 isolated in Bangalore. Pol J Microbiol 58(1):29-36.

Yandri, Susanti D, Suhartati T, Hadi S (2012) Immobilization of $\alpha$-amylase from locale bacteria isolate Bacillus subtilis ITBCCB148 with carboxymethyl cellulose (CMCellulose). Modern Appl Sci 6(3). 